Article

\title{
Tipburn Incidence and Ca Acquisition and Distribution in Lisianthus (Eustoma grandiflorum (Raf.) Shinn.) Cultivars under Different Ca Concentrations in Nutrient Solution
}

\author{
Takanori Kuronuma *, Masaya Ando and Hitoshi Watanabe * \\ Center for Environment, Health and Field Sciences, Chiba University, 6-2-1 Kashiwa-no-ha, Kashiwa-City, \\ Chiba 277-0882, Japan; m-ando@chiba-u.jp \\ * Correspondence: t.kuronuma@chiba-u.jp (T.K.); hwatanabe@faculty.chiba-u.jp (H.W.); \\ Tel.: +81-47-137-8174 (T.K.); +81-47-137-8106 (H.W.)
}

Received: 8 January 2020; Accepted: 30 January 2020; Published: 3 February 2020

\begin{abstract}
Tipburn (calcium (Ca) deficiency disorder) is a major problem in the production of lisianthus cultivars. However, few studies have investigated the influence of different Ca concentrations in nutrient solution on tipburn incidence and $\mathrm{Ca}$ acquisition and distribution. Thus, it remains unclear why some cultivars exhibit tipburn under high Ca concentrations. To address this, we used three lisianthus cultivars 'Azuma-no-Kaori' (AK), 'Celeb Wine' (CW), and 'Voyage Yellow' (VY) and compared tipburn incidence and $\mathrm{Ca}$ acquisition and distribution under different $\mathrm{Ca}$ concentrations in a nutrient solution (low (40 ppm), moderate ( $80 \mathrm{ppm})$, and high $(120 \mathrm{ppm}) \mathrm{Ca})$. Tipburn severity and incidence in $\mathrm{AK}$ and VY significantly decreased with increasing nutritional $\mathrm{Ca}$ concentrations; the $\mathrm{Ca}$ concentrations in each organ and $\mathrm{Ca}$ acquisition competence $\left(\mathrm{RGR}_{\mathrm{Ca}}\right)$ increased at higher nutritional Ca concentrations. In contrast, tipburn incidence in CW was 100\% for all treatments. In CW, Ca acquisition competence and $\mathrm{Ca}$ concentrations in most organs increased with increasing nutritional Ca concentrations, but the Ca concentrations in the tips of the upper leaves did not differ significantly between treatments. Thus, our results suggest that the cause of tipburn under sufficient $\mathrm{Ca}$ conditions is an inability of the plant to distribute $\mathrm{Ca}$ to the tips of its upper leaves.
\end{abstract}

Keywords: Ca deficiency; Eustoma grandiflorum; growth analysis; path analysis

\section{Introduction}

Lisianthus (Eustoma grandiflorum (Raf.) Shinn.) is a species in the family Gentianaceae that originated in the warm regions of the southern United States and northern Mexico. Its cultivars are mainly supplied in the form of cut flowers. The wholesale value of lisianthus cultivars ranked fifth among cut flowers in Japan in 2017. In addition, most of the lisianthus cultivars produced around the world are bred by Japanese seed companies.

The occurrence of tipburn (calcium (Ca) deficiency disorder) is a major problem for the production of lisianthus cultivars because it causes shipment delay, deterioration in plant quality, and serious economic losses. The cause of tipburn has been widely investigated in commercial crops such as lettuce [1-5], Chinese cabbage [6-9], strawberries [10-13], and lilies [14-16].

Recent studies on lisianthus cultivars have shown that tipburn is mainly caused by the inability of the plant to translocate adequate amounts of Ca to the tips of the upper leaves, which is associated with an increase in the distribution of $\mathrm{Ca}$ in the roots $[17,18]$. It has been suggested that changes in plant and organ growth rates have little effect on the incidence of tipburn in lisianthus [18]. However, few studies have compared tipburn incidence and $\mathrm{Ca}$ acquisition and distribution under different 
Ca concentrations in nutrient solution for lisianthus cultivars. Thus, it remains unclear why some lisianthus cultivars exhibit tipburn even under conditions of high Ca concentrations.

Acquisition competence of elements (e.g., calcium, carbon, nitrogen) has been quantified by applying growth analysis methods [17-21]. In addition, path analysis has been conducted to quantify the relevance of the relative growth rate (RGR) and its components (e.g., leaf area ratio (LAR), net assimilation rate (NAR), specific leaf area (SLA), and specific nitrogen absorption rate (SAR) in roots) in plant ecology [22-25]. Under different nutritional Ca concentrations, Ca distribution to the upper leaves seems to be affected by changes in Ca acquisition. However, no studies to date have quantified the roles of $\mathrm{Ca}$ acquisition and distribution under different nutritional $\mathrm{Ca}$ concentrations. Thus, in this study, we attempted to address this knowledge gap by applying growth and path analyses.

The aims of the present study were to elucidate the influence of different Ca concentrations in nutrient solution on tipburn incidence and $\mathrm{Ca}$ acquisition and distribution in three lisianthus cultivars and to discuss the causes of tipburn under high Ca concentrations. In addition, path analysis was conducted to quantify the roles of $\mathrm{Ca}$ acquisition and distribution.

\section{Materials and Methods}

\subsection{Plants}

The lisianthus cultivars used in this study were 'Azuma-no-Kaori' (AK) (Sakata Seed Corporation, Yokohama, Japan), 'Celeb Wine' (CW) (Sumika Agrotech Co., Ltd., Osaka City, Japan), and 'Voyage Yellow' (VY) (Sakata Seed Corporation), which were selected from a group classified in a previous study [17]. AK has been classified as tipburn-sensitive with high Ca requirements, and CW has been classified as tipburn-sensitive with low ability to acquire $\mathrm{Ca}$ and distribute it to the tips of its upper leaves; VY has been classified as tipburn-sensitive with low ability to distribute Ca to the tips of its upper leaves.

Seeds were sown in plug flats (406 cells per tray) filled with seedling propagation medium (Metro Mix 350; Sun Gro Horticulture, Agawam, MA, USA) on 17 March 2018. The seeded trays were maintained in a germination room at $24^{\circ} \mathrm{C}$ under a $14 \mathrm{~h}$ light $/ 10 \mathrm{~h}$ dark photoperiod. After two weeks, the trays were transferred to a controlled environmental system (phytotron), and the plants were grown under the following conditions: $25^{\circ} \mathrm{C}$ (light period) and $20^{\circ} \mathrm{C}$ (dark period), $60 \pm 5 \%$ humidity, $400 \mathrm{ppm} \mathrm{CO}$, $14 \mathrm{~h}$ light $\left(225 \pm 25 \mu \mathrm{mol} \mathrm{m} \mathrm{m}^{-2} \mathrm{~s}^{-1}\right)$ and $10 \mathrm{~h}$ dark. An irrigation system in the phytotron supplied a nutrient solution by bottom watering for $30 \mathrm{~min}$ at once a day. The nutrient solution was made by dissolving nutrient salts in distilled water $\left(\mathrm{KNO}_{3}\right.$ (Fujifilm Wako Chemicals U.S.A. Corporation, Richmond, VA, USA): $0.202 \mathrm{~g} / \mathrm{L}, \mathrm{Ca}\left(\mathrm{NO}_{3}\right)_{2} \bullet 4 \mathrm{H}_{2} \mathrm{O}$ (Fujifilm Wako Chemicals U.S.A. Corporation): $0.236 \mathrm{~g} / \mathrm{L}, \mathrm{NH}_{4} \mathrm{H}_{2} \mathrm{PO}_{4}$ (Fujifilm Wako Chemicals U.S.A. Corporation): $0.038 \mathrm{~g} / \mathrm{L}$, $\mathrm{MgSO}_{4} \bullet 7 \mathrm{H}_{2} \mathrm{O}$ (Fujifilm Wako Chemicals U.S.A. Corporation): $0.123 \mathrm{~g} / \mathrm{L}$, Otsuka-house No.5 L (OAT Agrio Co., Ltd., Tokyo, Japan): $0.4 \mathrm{~mL} / \mathrm{L}$ ) and its nutrient concentrations were same as that used in previous studies $[17,18,26]$. Five weeks after transfer to the phytotron, plugs were transplanted into $0.25 \mathrm{~L}$ polyethylene pots filled with Metro Mix 350.

\subsection{Experimental Design}

Individuals of the three cultivars were assigned randomly to either low (40 ppm Ca), moderate ( 80 ppm Ca), or high Ca treatments (120 ppm Ca). Plants in the low Ca treatment were supplied with the same nutrient solution as described above. In order to minimize the influence of incremental changes in nutrients other than $\mathrm{Ca}, \mathrm{CaCl}_{2}$ (Fujifilm Wako Chemicals U.S.A. Corporation) was added to the nutrient solution in the moderate (added $\mathrm{CaCl}_{2}: 0.147 \mathrm{~g} / \mathrm{L}$ ) and high Ca treatments (added $\mathrm{CaCl}_{2}: 0.294$ $\mathrm{g} / \mathrm{L}$ ). Although the $\mathrm{Cl}$ concentrations in the nutrient solutions for these treatments (moderate: $71 \mathrm{ppm}$ $\mathrm{Cl}$, high: $142 \mathrm{ppm} \mathrm{Cl}$ ) appear to be high, these values are lower than the reference values for raw water for nutrient solutions in Japan. The supplied nutrient solutions were replaced every two weeks. All plants were maintained in the same phytotron under the environmental conditions described above. 
At the start of the experiment, five pots of each cultivar were randomly sampled in triplicate. Plant dry weights and $\mathrm{Ca}$ concentrations in all plant organs were measured. No tipburn was observed in any of the cultivars at that stage. Eight weeks later, a total of 15 pots ( 5 pots $\times 3$ replicates) were sampled from all treatments, and the tipburn severity and incidence and Ca acquisition and distribution were investigated. Harvested plants were washed with distilled water and divided into roots, stems, and leaves to measure Ca concentrations and dry weights. In addition, to evaluate vertical Ca distribution in each cultivar, the 1st (upper), 4th (middle), and 7th (lower) leaves on the main stem (leaf position was counted from the top to the base) were distinguished.

\subsection{Tipburn Severity and Incidence}

Whole leaves were scored using an arbitrary tipburn severity index with ranking from 0 to $1(0$, asymptomatic; 0.2 , deformed leaf margins; 0.5 , leaf-tip chlorosis; 1 , leaf-tip necrosis) [26]. The severity of tipburn in each plant was defined as

Tipburn severity $=\sum\{($ severity index $\times$ leaf number $) /$ whole leaves number per pot $\} \times 100$

The incidence of tipburn (tipburn incidence) was expressed as the percentage of plants in a cultivar exhibiting tipburn symptoms.

\subsection{Measurement of Dry Weight and Ca Concentration}

Samples of plant organs were dried at $70{ }^{\circ} \mathrm{C}$ for $72 \mathrm{~h}$ and weighed. To evaluate morphological responses to different $\mathrm{Ca}$ concentrations, leaf mass ratio (LMR; leaf mass/whole-plant mass), stem mass ratio (SMR; stem mass/whole-plant mass), and root mass ratio (RMR; root mass/whole-plant mass) were calculated. Ca concentrations were determined using a Z-5300 polarized Zeeman atomic absorption spectrophotometer (Hitachi, Ltd., Tokyo, Japan). To evaluate horizontal Ca distribution for each leaf position, Ca concentrations of the top one-fifth (leaf tip) and the remainder (leaf base) of each leaf (the 1st (upper), 4th (middle), and 7th (lower) leaves) were analyzed separately. To calculate total Ca concentrations, we quantified the whole-plant $\mathrm{Ca}$ content by adding the Ca content (Ca concentration $\times$ dry weight) of each organ. Total Ca concentrations were calculated by dividing the whole-plant $\mathrm{Ca}$ content by the mass of the whole plant. Ca concentrations of whole leaves were similarly determined.

\subsection{Ca acquisition Competence}

The Ca acquisition competence $\left(\mathrm{RGR}_{\mathrm{Ca}}\right)$ for each plant was defined as

$$
\operatorname{RGR}_{\mathrm{Ca}}=\left(\ln \mathrm{W}_{\mathrm{Ca} 2}-\ln \mathrm{W}_{\mathrm{Ca} 1}\right) /\left(\mathrm{T}_{2}-\mathrm{T}_{1}\right)
$$

where $W_{C a 1}$ and $W_{C a 2}$ are the whole-plant $C$ a content at times $T_{1}$ and $T_{2}$, respectively. In addition, the specific $\mathrm{Ca}$ absorption rate per unit root mass $\left(\mathrm{SAR}_{\mathrm{Ca}}\right)$ and the root mass ratio per whole-plant $\mathrm{Ca}$ content $\left(\mathrm{RMR}_{\mathrm{Ca}}\right)$ were calculated using the following equations [17-19,27].

$$
\begin{gathered}
\mathrm{SAR}_{\mathrm{Ca}}=\left(\mathrm{W}_{\mathrm{Ca} 2}-\mathrm{W}_{\mathrm{Ca} 1}\right) /\left(\mathrm{T}_{2}-\mathrm{T}_{1}\right) \times\left(\ln \mathrm{W}_{\mathrm{R} 2}-\ln \mathrm{W}_{\mathrm{R} 1}\right) /\left(\mathrm{W}_{\mathrm{R} 2}-\mathrm{W}_{\mathrm{R} 1}\right) \\
\mathrm{RMR}_{\mathrm{Ca}}=\left(\mathrm{W}_{\mathrm{R} 2 /} \mathrm{W}_{\mathrm{Ca} 2}+\mathrm{W}_{\mathrm{R} 1} / \mathrm{W}_{\mathrm{Ca} 1}\right) / 2
\end{gathered}
$$

where $W_{R 1}$ and $W_{R 2}$ are the root dry weights at times $T_{1}$ and $T_{2}$, respectively.

\subsection{Statistical Analysis}

Data were analyzed using SPSS v.22.0 (IBM Corp. Japan, Tokyo, Japan). A one-way ANOVA (analysis of variance) was conducted to assess the effects of the treatments. Differences in mean values were evaluated using Tukey's b (homoscedasticity assumed) or Dunnet T3 (homoscedasticity not assumed) tests. The mean values are presented. For the path analysis, SPSS Amos 25 (IBM Corp.) was 
used. Pathway analysis was performed on Ca concentrations in the tips of the upper (1st) and lower (7th) leaves, Ca acquisition competence $\left(\mathrm{RGR}_{\mathrm{Ca}}\right)$, and its components $\left(\mathrm{SAR}_{\mathrm{Ca}}\right.$ and $\left.\mathrm{RMR}_{\mathrm{Ca}}\right)$.

\section{Results and Discussion}

\subsection{Tipburn Severity and Incidence}

The tipburn severity and incidence for each cultivar and treatment are shown in Figure 1. For $\mathrm{AK}$ and VY, tipburn severity and incidence decreased at higher Ca concentrations. In contrast, $\mathrm{CW}$ exhibited tipburn in all plants (tipburn incidence $=100 \%$ ) and tipburn severity was higher than $10 \%$ even in the high Ca treatment. These results indicate that Ca application is not an effective approach to eliminate tipburn in some lisianthus cultivars.

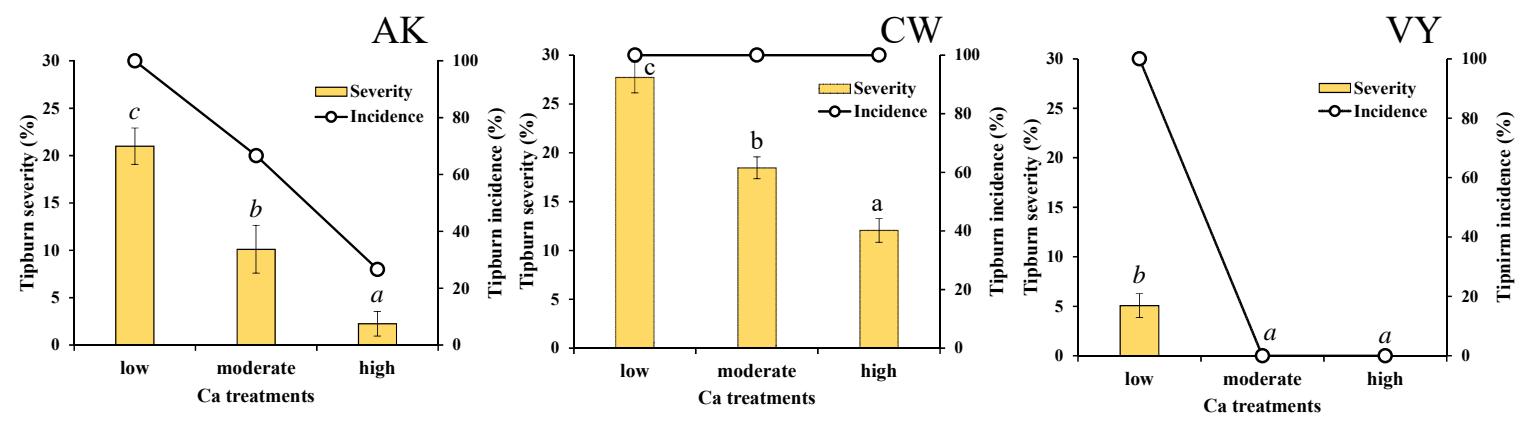

Figure 1. Tipburn severity and incidence for three lisianthus cultivars and Ca concentration treatments at the end of the experiment. Mean values $(n=15)$ are shown, and significant differences among them are indicated by different letters (normal type: Tukey's b test, $p<0.05$; italic type: Dunnet T3, $p<0.05$ ). Cultivars: 'Azuma-no-Kaori' (AK), 'Celeb Wine' (CW), 'Voyage Yellow' (VY).

\subsection{Plant Growth}

Every cultivar exhibited the lowest plant dry weight and RMR in the low Ca treatment (Table 1). There were no significant differences in the LMR of any cultivar between treatments. The SMR of each cultivar tended to decrease with increasing nutritional Ca concentration.

Table 1. Plant dry weight, leaf mass ratio (LMR), stem mass ratio (SMR), and root mass ratio (RMR) for each cultivar and treatment at the end of the experiment.

\begin{tabular}{cccccccccc}
\hline Cultivars & Treatments & \multicolumn{2}{c}{ Dry Weight (g) } & \multicolumn{2}{c}{ LMR (g/g) } & \multicolumn{2}{c}{ SMR (g/g) } & \multicolumn{2}{c}{ RMR (g/g) } \\
\hline \multirow{3}{*}{ AK } & low & 3.7 & $\mathrm{a}$ & 0.56 & & 0.20 & $\mathrm{c}$ & 0.24 & $\mathrm{a}$ \\
& moderate & 5.4 & $\mathrm{~b}$ & 0.55 & n.s. & 0.18 & $\mathrm{~b}$ & 0.27 & $\mathrm{ab}$ \\
& high & 5.0 & $\mathrm{~b}$ & 0.55 & & 0.15 & $\mathrm{a}$ & 0.30 & $\mathrm{~b}$ \\
\hline \multirow{2}{*}{$\mathrm{CW}$} & low & 4.2 & $\mathrm{a}$ & 0.63 & & 0.18 & $\mathrm{~b}$ & 0.19 & $\mathrm{a}$ \\
& moderate & 5.2 & $\mathrm{ab}$ & 0.61 & n.s. & 0.16 & $\mathrm{a}$ & 0.23 & $\mathrm{ab}$ \\
& high & 5.9 & $\mathrm{~b}$ & 0.59 & & 0.16 & $\mathrm{a}$ & 0.24 & $\mathrm{~b}$ \\
\hline \multirow{2}{*}{$\mathrm{VY}$} & low & 4.6 & $\mathrm{a}$ & 0.57 & & 0.14 & $\mathrm{~b}$ & 0.29 & \\
& moderate & 5.5 & $\mathrm{~b}$ & 0.57 & n.s. & 0.11 & $\mathrm{a}$ & 0.31 & n.s. \\
& high & 5.4 & $\mathrm{~b}$ & 0.57 & & 0.12 & $\mathrm{ab}$ & 0.31 & \\
\hline
\end{tabular}

Mean values $(n=15)$ are shown, and significant differences among them are indicated by different letters (normal type: Tukey's b test, $p<0.05$; italic type: Dunnet T3, $p<0.05)$. n.s. represent no significant differences among the treatments (ANOVA, $p>0.05$ ). Cultivars: 'Azuma-no-Kaori' (AK), 'Celeb Wine' (CW), 'Voyage Yellow' (VY).

The results for dry weight (Table 1) and tipburn severity and incidence (Figure 1) demonstrate that plant growth inhibition by tipburn occurrence was reduced at high Ca concentrations (moderate and high). Increases in RMR under high Ca concentrations can be attributed to increases in plant dry weight and water consumption of the plant. In addition, $\mathrm{Ca}$ and $\mathrm{Cl}$ excess disorder were not observed 
in this experiment, indicating that differences in $\mathrm{Cl}$ concentrations in the nutrient solution had little effect on plant growth.

\subsection{Ca Acquisition Competence}

Total Ca concentration, $\mathrm{RGR}_{\mathrm{Ca}}, \mathrm{SAR}_{\mathrm{Ca}}$, and $\mathrm{RMR}_{\mathrm{Ca}}$ of each cultivar and treatment are shown in Table 2. Total Ca concentrations and $\mathrm{RGR}_{\mathrm{Ca}}$ of each cultivar increased with increasing nutritional $\mathrm{Ca}$ concentration and there were significant differences in those values between low and high $\mathrm{Ca}$ treatments. The $\mathrm{SAR}_{\mathrm{Ca}}$ of each cultivar increased similarly to total Ca concentrations and $\mathrm{RGR}_{\mathrm{Ca}}$. In contrast, no increases in $\mathrm{RMR}_{\mathrm{Ca}}$ with increasing Ca concentration were observed in any of the cultivars.

Table 2. Total Ca concentrations, $\mathrm{Ca}$ acquisition competence $\left(\mathrm{RGR}_{\mathrm{Ca}}\right)$, specific $\mathrm{Ca}$ absorption rate per unit root mass $\left(\mathrm{SAR}_{\mathrm{Ca}}\right)$, and root mass ratio per whole-plant Ca content $\left(\mathrm{RMR}_{\mathrm{Ca}}\right)$ for each cultivar and treatment at the end of the experiment.

\begin{tabular}{|c|c|c|c|c|c|c|c|c|c|}
\hline \multirow{2}{*}{ Cultivars } & \multirow{2}{*}{ Treatments } & \multicolumn{2}{|c|}{ Total Ca Concentrations } & \multicolumn{2}{|c|}{$\mathbf{R G R}_{\mathrm{Ca}}$} & \multicolumn{2}{|c|}{ SAR $_{\mathrm{Ca}}$} & \multirow{2}{*}{\multicolumn{2}{|c|}{$\frac{\mathrm{RMR}_{\mathrm{Ca}}}{(\mathrm{mg}-\mathrm{Ca} / \mathrm{g}-\mathrm{DW})}$}} \\
\hline & & \multicolumn{2}{|c|}{ (mg-Ca/kg-DW) } & \multicolumn{2}{|c|}{$\left(\mathrm{mg}-\mathrm{Ca} \mathrm{mg-Ca}{ }^{-1}\right.$ week $^{-1}$ ) } & \multicolumn{2}{|c|}{ (mg-Ca g-DW-1 week $^{-1}$ ) } & & \\
\hline \multirow{2}{*}{ AK } & low & 2.7 & $\mathrm{a}$ & 0.59 & $a$ & 6.1 & $\mathrm{a}$ & 0.11 & \\
\hline & high & 4.4 & $\mathrm{~b}$ & 0.69 & $b$ & 9.1 & $\mathrm{~b}$ & 0.10 & \\
\hline \multirow[b]{2}{*}{$\mathrm{CW}$} & low & 2.7 & $\mathrm{a}$ & 0.60 & $\mathrm{a}$ & 7.4 & $\mathrm{a}$ & 0.10 & $\mathrm{~b}$ \\
\hline & moderate & 3.8 & $\mathrm{~b}$ & 0.67 & $\mathrm{~b}$ & 9.7 & $\mathrm{~b}$ & 0.09 & a \\
\hline \multirow{3}{*}{ VY } & low & 2.7 & $a$ & 0.66 & $\mathrm{a}$ & 6.4 & $\mathrm{a}$ & 0.10 & $\mathrm{~b}$ \\
\hline & moderate & 3.8 & $b$ & 0.73 & $\mathrm{~b}$ & 8.7 & $\mathrm{~b}$ & 0.09 & $\mathrm{ab}$ \\
\hline & high & 4.6 & $c$ & 0.75 & $\mathrm{~b}$ & 10.8 & c & 0.08 & $\mathrm{a}$ \\
\hline
\end{tabular}

Mean values $(n=15)$ are shown, and significant differences among them are indicated by different letters (normal type: Tukey's b test, $p<0.05$; italic type: Dunnet T3, $p<0.05)$. n.s. represent no significant differences among the treatments (ANOVA, $p>0.05$ ). Cultivars: 'Azuma-no-Kaori' (AK), 'Celeb Wine' (CW), 'Voyage Yellow' (VY).

Although we hypothesized that Ca acquisition of tipburn-sensitive cultivars would not increase under high Ca concentrations, our results demonstrated that, in fact, Ca acquisition in all of the cultivars increased with increasing nutritional Ca concentration. Thus, the changes in Ca acquisition under different $\mathrm{Ca}$ concentrations appeared to have little effect on tipburn incidence for the lisianthus cultivars studied. In addition, Ca acquisition competence was strongly affected by a change in SAR $\mathrm{Ca}$. This finding suggests that variation in $\mathrm{Ca}$ acquisition under different $\mathrm{Ca}$ concentrations is mainly a result of physiological responses $\left(\mathrm{SAR}_{\mathrm{Ca}}\right)$ rather than morphological responses $\left(\mathrm{RMR}_{\mathrm{Ca}}\right)$.

\subsection{Ca Distribution}

\subsubsection{Ca Concentrations of Whole Leaves, Stems, and Roots}

The Ca concentrations of each organ for the three cultivars are shown in Table 3. Ca concentrations of all the organs in each cultivar showed a tendency to increase with increasing nutritional $\mathrm{Ca}$ concentration. These results were consistent with the results for $\mathrm{RGR}_{\mathrm{Ca}}$ and total Ca concentrations.

\subsubsection{Ca Concentrations of Upper (1st), Middle (4th), and Lower (7th) Leaves}

For AK and VY-which showed lower tipburn incidence and severity with increasing nutritional Ca concentration (Figure 1) - Ca concentrations in the tips and bases of every leaf position increased at higher Ca concentrations (Table 4); similar results were seen in the other organs in AK and VY (Tables 2 and 3). In contrast, in CW-which had a tipburn incidence of $100 \%$ under all treatments (Figure 1) - Ca concentrations in the tips of the upper (1st) and middle (4th) leaves did not differ significantly between treatments, although concentrations in the leaf bases significantly increased with increasing nutritional Ca concentration (Table 4). These results indicate that lisianthus cultivars, which exhibit high tipburn incidence and severity under high nutritional Ca concentrations, have limited ability to distribute adequate $\mathrm{Ca}$ to the tips of the upper leaves; this was clearly the cause of tipburn 
under sufficient Ca concentrations. Lee et al. [28] reported that the expression of genes encoding $\mathrm{Ca}^{2+}$ vacuole transporters in cabbage cultivars is associated with accumulation of $\mathrm{Ca}^{2+}$ in the vacuoles of leaf cells. To elucidate why tipburn-sensitive lisianthus cultivars cannot distribute adequate Ca to the tips of upper leaves, the roles of Ca distribution and gene expression should be investigated in the future. In addition, further researches on the effect of different Ca supply on tipburn incidence in the other cultivars also need.

Table 3. Ca concentrations of whole leaves, upper stems, lower stems, and roots for each cultivar and treatment at the end of the experiment.

\begin{tabular}{cccccccccc}
\hline \multirow{2}{*}{ Cultivars } & Treatments & \multicolumn{7}{c}{ Ca Concentrations (mg-Ca/kg-DW) } \\
\cline { 3 - 9 } & & Whole Leaves & \multicolumn{2}{c}{ Upper Stems } & Lower Stems & \multicolumn{2}{c}{ Roots } \\
\hline \multirow{3}{*}{ AK } & low & 1.6 & $\mathrm{a}$ & 0.52 & $a$ & 0.60 & $a$ & 6.79 & $\mathrm{a}$ \\
& moderate & 2.0 & $\mathrm{~b}$ & 0.87 & $b$ & 0.93 & $\mathrm{~b}$ & 9.44 & $\mathrm{~b}$ \\
& high & 2.2 & $\mathrm{c}$ & 0.96 & $b$ & 1.11 & $\mathrm{~b}$ & 9.81 & $\mathrm{~b}$ \\
\hline \multirow{3}{*}{$\mathrm{CW}$} & low & 1.6 & $\mathrm{a}$ & 0.80 & $a$ & 0.95 & $\mathrm{a}$ & 7.69 & $\mathrm{a}$ \\
& moderate & 2.1 & $\mathrm{~b}$ & 1.58 & $\mathrm{~b}$ & 1.10 & $\mathrm{~b}$ & 9.89 & $\mathrm{~b}$ \\
& high & 2.6 & $\mathrm{c}$ & 2.24 & $\mathrm{c}$ & 1.45 & $\mathrm{~b}$ & 11.09 & $\mathrm{c}$ \\
\hline \multirow{3}{*}{$\mathrm{VY}$} & low & 1.0 & $\mathrm{a}$ & 0.75 & $\mathrm{a}$ & 0.65 & $\mathrm{a}$ & 7.02 & $\mathrm{a}$ \\
& moderate & 2.2 & $\mathrm{~b}$ & 1.19 & $\mathrm{~b}$ & 1.00 & $\mathrm{~b}$ & 7.51 & $\mathrm{a}$ \\
& high & 2.7 & $\mathrm{c}$ & 1.70 & $\mathrm{c}$ & 1.13 & $\mathrm{~b}$ & 9.35 & $\mathrm{~b}$ \\
\hline
\end{tabular}

Mean values $(n=15)$ are shown, and significant differences among them are indicated by different letters (normal type: Tukey's b test, $p<0.05$; italic type: Dunnet T3, $p<0.05$ ). Cultivars: 'Azuma-no-Kaori' (AK), 'Celeb Wine' (CW), 'Voyage Yellow' (VY).

Table 4. Ca concentrations in the tips and bases of upper (1st), middle (4th), and lower (7th) leaves for each cultivar and treatment at the end of the experiment.

\begin{tabular}{|c|c|c|c|c|c|c|c|c|c|c|c|c|c|}
\hline \multirow{4}{*}{ Cultivars } & \multirow{3}{*}{ Treatments } & \multicolumn{12}{|c|}{ Ca Concentrations (mg-Ca/kg-DW) } \\
\hline & & \multicolumn{4}{|c|}{ Upper (1st) Leaves } & \multicolumn{4}{|c|}{ Middle (4th) Leaves } & \multicolumn{4}{|c|}{ Lower (7th) Leaves } \\
\hline & & \multicolumn{2}{|c|}{ Tips } & \multicolumn{2}{|c|}{ Bases } & \multicolumn{2}{|c|}{ Tips } & \multicolumn{2}{|c|}{ Bases } & \multicolumn{2}{|c|}{ Tips } & \multicolumn{2}{|c|}{ Bases } \\
\hline & low & 1.77 & $a$ & 1.29 & a & 1.33 & $a$ & 1.09 & a & 1.92 & a & 1.08 & $a$ \\
\hline \multirow[t]{2}{*}{ AK } & moderate & 2.50 & $b$ & 1.73 & $\mathrm{~b}$ & 2.01 & $b$ & 1.88 & $\mathrm{~b}$ & 2.28 & $\mathrm{~b}$ & 1.57 & $b$ \\
\hline & high & 3.28 & $b$ & 1.88 & $\mathrm{~b}$ & 2.39 & $c$ & 2.13 & c & 2.42 & $\mathrm{~b}$ & 1.74 & $b$ \\
\hline \multirow{3}{*}{$\mathrm{CW}$} & low & 2.15 & & 1.55 & $\mathrm{a}$ & 1.79 & & 1.77 & a & 1.63 & $\mathrm{a}$ & 1.43 & a \\
\hline & moderate & 1.85 & n.s. & 2.31 & $b$ & 1.78 & n.s. & 2.68 & $\mathrm{~b}$ & 1.77 & $a b$ & 2.01 & $\mathrm{~b}$ \\
\hline & high & 1.85 & & 3.09 & c & 1.86 & & 3.44 & c & 2.12 & $\mathrm{~b}$ & 2.71 & c \\
\hline \multirow{3}{*}{ VY } & low & 1.52 & $a$ & 1.36 & $\mathrm{a}$ & 1.75 & $a$ & 1.51 & $a$ & 1.81 & a & 1.37 & $\mathrm{a}$ \\
\hline & moderate & 3.52 & $b$ & 1.90 & $a b$ & 2.27 & $b$ & 2.23 & $b$ & 2.23 & $b$ & 2.16 & $\mathrm{~b}$ \\
\hline & high & 3.36 & $b$ & 2.72 & $\mathrm{~b}$ & 2.45 & $b$ & 2.69 & $c$ & 2.06 & $\mathrm{~b}$ & 2.39 & $\mathrm{~b}$ \\
\hline
\end{tabular}

Mean values $(n=15)$ are shown, and significant differences among them are indicated by different letters (normal type: Tukey's b test, $p<0.05$; italic type: Dunnet T3, $p<0.05)$. n.s. represent no significant differences among the treatments (ANOVA, $p>0.05$ ). Cultivars: 'Azuma-no-Kaori' (AK), 'Celeb Wine' (CW), 'Voyage Yellow' (VY).

\subsection{Contributions of $\mathrm{Ca}$ Acquisition and Ca Distribution under Different $\mathrm{Ca}$ Concentrations}

Path models for CW and VY were constructed for all treatments (Figure 2) and were not rejected (CW: $\chi^{2}=2.362, p=0.797$; VY: $\chi^{2}=6.329, p=0.275$ ). These path models provided a good explanation of the contributions of Ca acquisition and distribution for leaf tips (CW: GFI (goodness of fit index) = 0.979, AGFI (adjusted GFI) $=0.937, \mathrm{CFI}$ (comparative fix index) $=1.000$, RMSEA (root means square error of approximation) $=0.000$; VY: GFI $=0.948$, AGFI $=0.843, \mathrm{CFI}=0.986$, RMSEA $=0.078)$. In contrast, the same path model for AK was rejected $\left(\chi^{2}=29.066, p=0.000\right)$. 


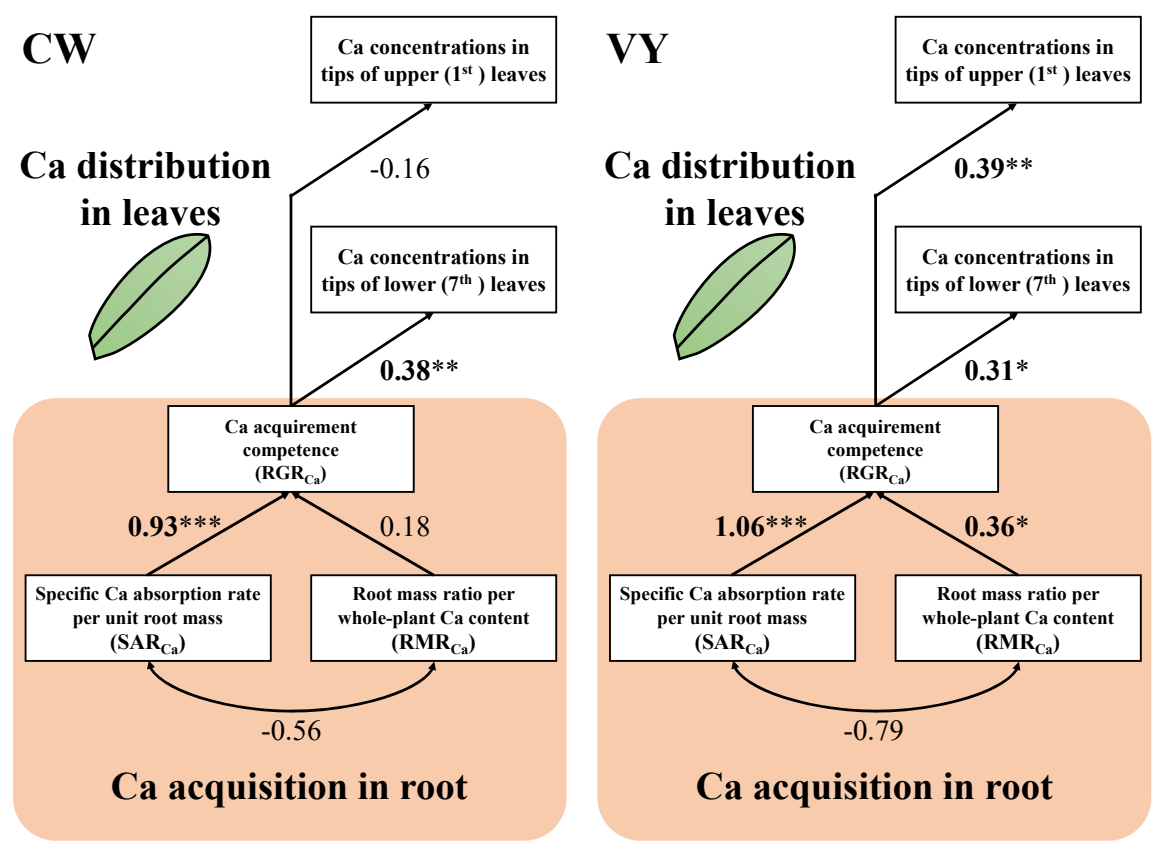

Figure 2. Path model of $\mathrm{Ca}$ acquisition competence $\left(\mathrm{RGR}_{\mathrm{Ca}}\right)$, specific absorption rate per unit. root mass $\left(\mathrm{SAR}_{\mathrm{Ca}}\right)$, root mass ratio per whole-plant Ca content $\left(\mathrm{RMR}_{\mathrm{Ca}}\right)$, and Ca concentrations in the tips of upper (1st) and lower (7th) leaves under three different Ca treatments for 'Celeb Wine '(CW) and 'Voyage Yellow' (VY) lisianthus cultivars. Single-arrow lines represent causal relationships and the numbers above the arrows are the standardized path coefficients. Double-arrow lines represent correlations and the numbers above the arrows are standardized correlation coefficients. The significance levels of the path effects are indicated by ${ }^{*} p<0.05 ;{ }^{* *} p<0.01 ;{ }^{* * *} p<0.001$.

Path standardized coefficients for $\mathrm{SAR}_{\mathrm{Ca}}$ to $\mathrm{RGR}_{\mathrm{Ca}}$ of each cultivar were significant and higher than those for $\mathrm{RMR}_{\mathrm{Ca}}$ to $\mathrm{RGR}_{\mathrm{Ca}}$ (Figure 2), indicating that $\mathrm{Ca}$ acquisition competence was strongly affected by physiological responses (changes in $\mathrm{SAR}_{\mathrm{Ca}}$ ). For VY, the path standardized coefficient for $\mathrm{RGR}_{\mathrm{Ca}}$ to Ca concentrations in the tips of upper (1st) and lower (7th) leaves were significant and had similar values. In contrast, for $\mathrm{CW}$, the path standardized coefficient for $\mathrm{RGR}_{\mathrm{Ca}}$ to $\mathrm{Ca}$ concentrations in the tips of the upper (1st) leaves was not significant and was distinctively lower than that for the lower (7th) leaves. These results demonstrate that tipburn-sensitive lisianthus cultivars have limited ability to distribute adequate $\mathrm{Ca}$ to the tips of upper leaves, although $\mathrm{Ca}$ acquisition and Ca distribution to other organs increased with increasing nutritional Ca concentration. In this study, we could not construct an effective path model for all the cultivars although many attempts have been conducted. To address this, in the future, quantification of other physiological and morphological traits also needs to be discussed in more detail.

\section{Conclusions}

This study investigated the influence of Ca concentrations in nutrient solution on tipburn incidence and $\mathrm{Ca}$ acquisition and distribution in three lisianthus cultivars. At higher Ca concentrations, AK and VY exhibited significantly higher $\mathrm{Ca}$ acquisition competence $\left(\mathrm{RGR}_{\mathrm{Ca}}\right)$ and Ca concentrations in all organs, and their tipburn severity and incidence declined. In contrast, CW exhibited 100\% tipburn incidence under all treatments (Figure 1) and the Ca concentrations in the tips of the upper (1st) and middle (4th) leaves did not differ significantly between treatments although Ca acquisition competence and $\mathrm{Ca}$ concentrations in other organs significantly increased with increasing nutritional Ca concentrations. Thus, the cause of tipburn under sufficient $\mathrm{Ca}$ conditions is the inability of the plant to distribute $\mathrm{Ca}$ to the tips of upper leaves. In addition, path analysis enabled us to describe the roles of $\mathrm{Ca}$ acquisition and $\mathrm{Ca}$ distribution for the tips of leaves. Use of this analytical method can contribute 
to our understanding of the interrelationships between multiple physiological and morphological plant traits.

Author Contributions: All of the authors contributed to the work in the paper. T.K. and H.W. designed the research. T.K. wrote the paper and collected the data. H.W. and M.A. provided advice and suggestions. All authors have read and agreed to the published version of the manuscript.

Funding: This research was funded by JSPS KAKENHI Grant Number JP19K15830.

Conflicts of Interest: The authors declare no conflict of interest.

\section{References}

1. Barta, D.J.; Tibbitts, T.W. Calcium localization in lettuce leaves with and without tipburn: Comparison of controlled-environment and field-grown plants. J. Am. Soc. Hortic. Sci. 1991, 116, 870-875. [CrossRef] [PubMed]

2. Wissemeier, A.H.; Zühlke, G. Relation between climatic variables, growth and the incidence of tipburn in field-grown lettuce as evaluated by simple, partial and multiple regression analysis. Sci. Hortic. 2002, 93, 193-204. [CrossRef]

3. Sago, Y. Effects of light intensity and growth rate on tipburn development and leaf calcium concentration in butterhead lettuce. HortScience 2016, 51, 1087-1091. [CrossRef]

4. Uno, Y.; Okubo, H.; Itoh, H.; Koyama, R. Reduction of leaf lettuce tipburn using an indicator cultivar. Sci. Hortic. 2016, 210, 14-18. [CrossRef]

5. Holmes, S.C.; Wells, D.E.; Pickens, J.M.; Kemble, J.M. Selection of Heat Tolerant Lettuce (Lactuca sativa L.) Cultivars Grown in Deep Water Culture and Their Marketability. Horticulturae 2019, 5, 50. [CrossRef]

6. Kuo, C.G.; Tsay, J.S.; Tsai, C.L.; Chen, R.J. Tipburn of Chinese cabbage in relation to calcium nutrition and distribution. Sci. Hortic. 1981, 14, 131-138. [CrossRef]

7. Aloni, B.; Pashkar, T.; Libel, R. The possible involvement of gibberellins and calcium in tipburn of Chinese cabbage: Study of intact plants and detached leaves. Plant Growth Regul. 1986, 4, 3-11. [CrossRef]

8. Pressman, E.; Shaked, R.; Arcan, L. The effect of flower-inducing factors on leaf tipburn formation in Chinese cabbage. J. Plant Physiol. 1993, 141, 210-214. [CrossRef]

9. Magnusson, M. Mineral fertilizers and green mulch in Chinese cabbage [Brassica pekinensis (Lour.) Rupr.]: Effect on nutrient uptake, yield and internal tipburn. Acta Agric. Scand. Sect. B Plant Soil Sci. 2002, 52, 25-35. [CrossRef]

10. Mason, G.F.; Guttridge, C.G. The influence of relative humidity and nutrition on leaf tipburn of strawberry. Sci. Hortic. 1975, 3, 339-349. [CrossRef]

11. Guttridge, C.G.; Bradfield, E.G.; Holder, R. Dependence of calcium transport into strawberry leaves on positive pressure in the xylem. Ann. Bot. 1981, 48, 473-480. [CrossRef]

12. Bautista, A.S.; López-Galarza, S.; Martínez, A.; Pascual, B.; Maroto, J.V. Influence of cation proportions of the nutrient solution on tipburn incidence in strawberry plants. J. Plant Nutr. 2009, 32, 1527-1539. [CrossRef]

13. Palencia, P.; Martinez, F.; Ribeiro, E.; Pestana, M.; Gama, F.; Saavedra, T.; de Varennes, A.; Correia, P.J. Relationship between tipburn and leaf mineral composition in strawberry. Sci. Hortic. 2010, 126, 242-246. [CrossRef]

14. Chang, Y.C.; Miller, W.B. Growth and calcium partitioning in Lilium 'Star Gazer' in relation to leaf calcium deficiency. J. Am. Soc. Hortic. Sci. 2003, 128, 788-796. [CrossRef]

15. Chang, Y.C.; Miller, W.B. The relationship between leaf enclosure, transpiration, and upper leaf necrosis on Lilium 'Star Gazer'. J. Am. Soc. Hortic. Sci. 2004, 129, 128-133. [CrossRef]

16. Chang, Y.C.; Miller, W.B. The development of upper leaf necrosis in Lilium 'Star Gazer'. J. Am. Soc. Hortic. Sci. 2005, 130, 759-766. [CrossRef]

17. Kuronuma, T.; Watanabe, Y.; Ando, M.; Watanabe, H. Relevance of tipburn incidence to the competence for Ca acquirement and Ca distributivity in lisianthus [Eustoma grandiflorum (Raf.) Shinn.] cultivars. Sci. Hortic. 2019, 246, 805-811. [CrossRef]

18. Kuronuma, T.; Kinoshita, N.; Ando, M.; Watanabe, H. Difference of Ca distribution before and after the onset of tipburn in lisianthus [Eustoma grandiflorum (Raf.) Shinn.] cultivars. Sci. Hortic. 2020, 261. [CrossRef] 
19. Garnier, E. Resource capture, biomass allocation and growth in herbaceous plants. Trends Ecol. Evol. 1991, 6, 126-131. [CrossRef]

20. Kuronuma, T.; Watanabe, H. Physiological and morphological traits and competence for carbon sequestration of several green roof plants under a controlled environmental system. J. Am. Soc. Hortic. Sci. 2016, 141, 583-590. [CrossRef]

21. Kuronuma, T.; Watanabe, H. Relevance of carbon sequestration to the physiological and morphological traits of several green roof plants during the first year after construction. Am. J. Plant Sci. 2016, 8, 14-27. [CrossRef]

22. Poorter, H.; Remkes, C. Leaf area ratio and net assimilation rate of 24 wild species differing in relative growth rate. Oecologia 1990, 83, 553-559. [CrossRef] [PubMed]

23. Osone, Y.; Ishida, A.; Tateno, M. Correlation between relative growth rate and specific leaf area requires associations of specific leaf area with nitrogen absorption rate of roots. New Phytol. 2008, 179, 417-427. [CrossRef] [PubMed]

24. Imada, S.; Yamanaka, N.; Tami, S. Contribution of root growth responses to leaf traits and relative growth rate of Populus alba under different water-table conditions. Trees 2010, 24, 1163-1172. [CrossRef]

25. Oguchi, R.; Ozaki, H.; Hanada, K.; Hikosaka, K. Which plant trait explains the variations in relative growth rate and its response to elevated carbon dioxide concentration among Arabidopsis thaliana ecotypes derived from a variety of habitats? Oecologia 2016, 180, 865-876. [CrossRef]

26. Kuronuma, T.; Watanabe, Y.; Ando, M.; Watanabe, H. Tipburn severity and calcium distribution in lisianthus (Eustoma Grandiflorum (Raf.) Shinn.) cultivars under different relative air humidity conditions. Agronomy 2018, 8, 218. [CrossRef]

27. Hunt, R. Plant Growth Curves: The Functional Approach to Plant Growth Analysis; Edward Arnold Ltd.: London, UK, 1982.

28. Lee, J.; Park, I.; Lee, Z.W.; Kim, S.W.; Baek, N.; Park, H.S.; Park, S.U.; Kwon, S.Y.; Kim, H. Regulation of the major vacuolar $\mathrm{Ca}^{2+}$ transporter genes, by intercellular $\mathrm{Ca}^{2+}$ concentration and abiotic stresses, in tip-burn resistant Brassica oleracea. Mol. Boil. Rep. 2013, 40, 177-188. [CrossRef]

(C) 2020 by the authors. Licensee MDPI, Basel, Switzerland. This article is an open access article distributed under the terms and conditions of the Creative Commons Attribution (CC BY) license (http://creativecommons.org/licenses/by/4.0/). 